\title{
Research on Effectiveness of Ideological and Political Education for College Students in the Big Data Era
}

\author{
Peng Liusheng \\ Hunan Vocational College of Modern Logistics, Changsha, 410131, China
}

Keywords: Big Data; College Students; Ideological Politics; Effectiveness

\begin{abstract}
This paper studies the effectiveness of college students' ideological and political work in the era of big data. First, it systematically elaborates the connotation of the effectiveness of the ideological and political work of college students in the era of big data. Second, it analyzes and reveals the problems in the ideological and political work in the era of big data. Finally, specific countermeasures have been put forward to promote the innovation of the ideological and political education mechanism for college students based on big data, and enhance educators' informatization capability, innovate research paradigms for big data, improve relevant rules and regulations, and standardize the processing and application procedures of big data, thus accurately grasping the college students' ideological trend.
\end{abstract}

\section{Introduction}

Looking at the revolution brought about by the big data, it is the major universities that bear the brunt of the waves. [1] Colleges and universities bring together the most advanced knowledge, the most active ideas, and the most extensive application of network technology, so their education, teaching, management and service mode are inevitably strongly impacted by the tide of big data. As college students with the most active minds and the most innovative impulses, their ideology, values, learning methods and behavioral habits will inevitably fluctuate drastically under the influence of big data. [2] Obviously, big data has become an unavoidable new era environment for colleges and universities. [3] It has brought new opportunities and challenges to ideological and political work and has given our college ideological and political educators new work requirements. How to understand, master and reasonably use big data technology to achieve a qualitative leap in college students' ideological and political education? How to promote the reform and innovation of college students' ideological and political education? This is a fundamental issue that relates to what kinds of people are currently trained in colleges and universities and how to cultivate them, and it is also a big issue that determine whether or not the fundamental tasks of strengthening moral education and cultivate college students can be achieved.

\section{The Connotation of College Students' Ideological And Political Education}

The ideological and political education of college students in the era of big data refers to the integration of theories, techniques, and methods of big data with certain ideas, political views, and moral norms. [4] It combines the characteristics of college students and permeates the entire process of the ideological and political education of college students, and fully pay attention to information collection, testing, assessment, implementation, regulation, research and other links of ideological and political education cultivation, and exert targeted, planned and organized influences to promote the scientific education of ideological and political education, and help them foster ideological and political morality that meets the social requirements.

\section{Problems in Ideological and Political Work for College Students in the Era of Big Data}

\subsection{Inability of educators' educational informatization}

At present, the ideological and political education workers in most colleges and universities in 
our country have not yet realized the importance of education informatization, and they still adopt some relatively simple and limited ideological and political work methods, such as questionnaires, interviews, and concentrated teaching. [5] If the ideological and political workers in colleges and universities can make full use of the characteristics of big data and carry out ideological and political work on students, this will not only enhance the effectiveness of ideological and political work, but also reduce the work burden of educators to some extent. The traditional single ideological and political work style will develop towards diversification.

\subsection{Teaching content is difficult to stimulate students' interest}

The traditional ideological and political work is that educators teach the students the contents of courses in class. The contents of the courses are relatively abstract, empty and lack of persuasion, making it difficult for students to understand. The disconnection between theoretical knowledge and practical life makes it easy for students to develop negative and exclusive psychology in the learning process of ideological and political work. As a result, the effectiveness of ideological and political work has been weakened to some extent. Some experts and scholars believe that the main reason that education content makes students difficult to accept is the setting of educational goals.

\subsection{Delayed information collection and processing}

In the era of big data, ideological and political educators can use the technological advantages of information integration and analyze the daily behaviors of college students. However, traditional survey methods, such as classroom surveys and questionnaires, are still the primary choices for many college students' ideological and political educators. In terms of statistical analysis software they chose, some simple analysis software can only produce relatively single results. Efficient and comprehensive data analysis still depends on the technological advantages of big data. Therefore, the ideological and political educators in universities are lagging behind in the collection and analysis of research information, and their findings are more or less disconnecting with reality.

\subsection{Students' education environment needs to be integrated}

The influence of network environment is only one of the problems faced by college students ideological and political education, and the impact of foreign culture should not be underestimated. The college students who have grown up in the network environment will leave a tremendous impact on his outlook on life and the establishment of values under the multi-cultural environment, and it will also be a great challenge to educators. In the case of relatively tight budget, cultural construction in colleges and universities has always been neglected. Lack of vitality and creativity has become the crux of the problem of campus culture. In order to better carry out ideological and political education in colleges and universities, and to train more excellent talents, we should also combine with big data to provide a better campus cultural environment for college students in the campus cultural construction.

\subsection{Incomplete mechanism of the ideological and political work}

First of all, the guarantee mechanism is not perfect enough. Nowadays, the ideological and political education work of college students in some colleges and universities is only regarded as a mechanism of ideological and political work for college students under administrative orders. They are unwilling to invest funds, but more importantly, it is not considered as a major task. Second, the feedback mechanism of information is also not ideal. Nowadays there are many problems in the work of ideological and political education for college students, such as unclear mental state of students, slow handling of emergencies, weak awareness of prevention and so on. The reason behind them is that the feedback mechanism lags behind in the current ideological and political work of college students. 


\section{Measures to Enhance the Effectiveness of Ideological and Political Work for College Students in the Era of Big Data}

This paper analyzes the problems existing in the ideological and political work in the era of big data, and constructs the "five-sphere" path for the ideological and political work of college students in the era of big data, as shown in Figure 1.

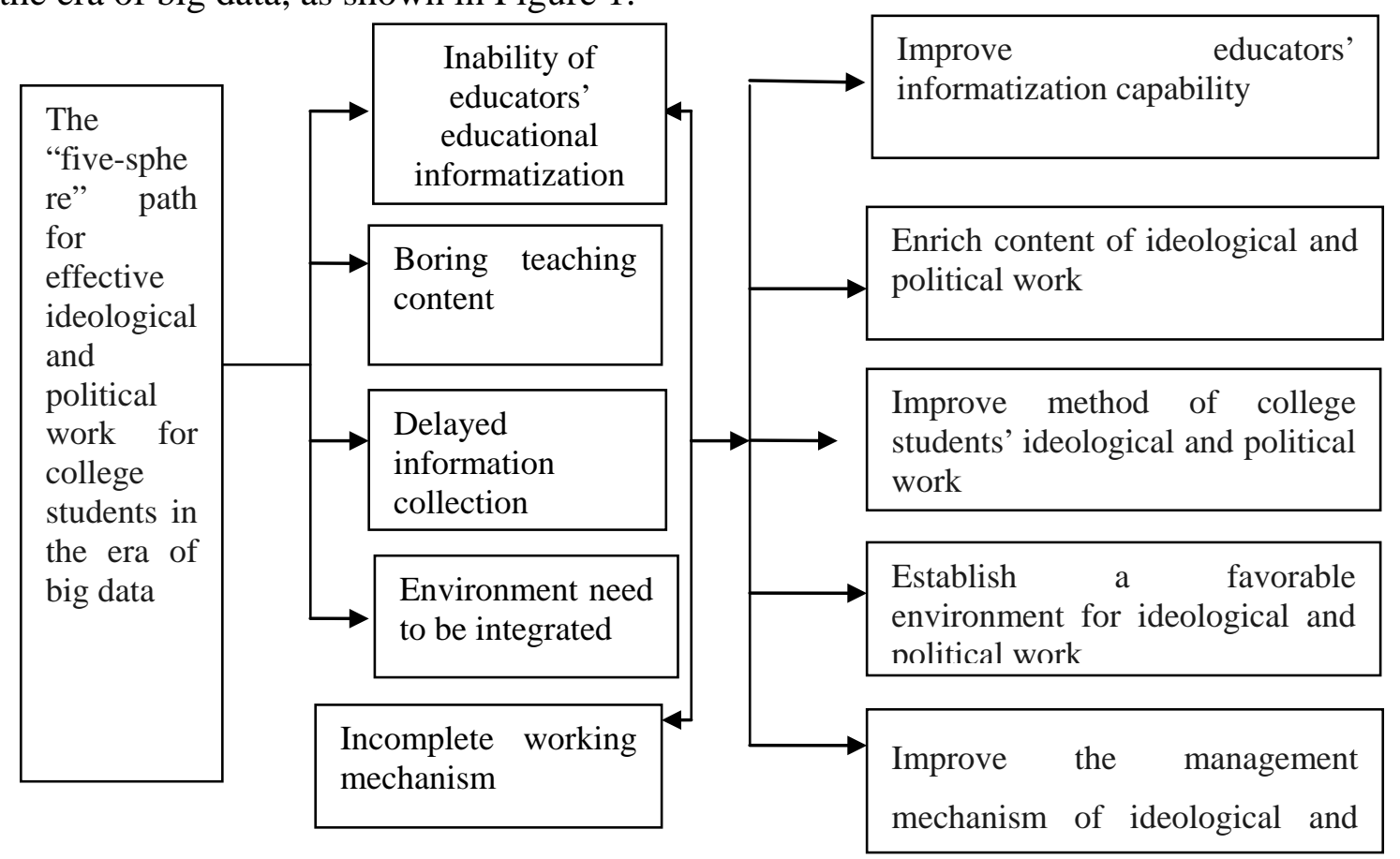

Figure 1 The "five-sphere” path for effective ideological and political work for college students in the era of big data

\subsection{Improve educators' informatization capability}

The improvement of educators' information attainment is mainly reflected in the following two aspects. On the one hand, college educators should fully understand various information technology knowledge and specific application forms in the era of big data. On the ideological level, they should fully consider that they can influence all aspects of ideological and political education. On the other hand, various information tools can be specifically applied in practice to assist work and maintain communication and interaction with students. In education and teaching, it can set good example for students and provide good guidance to students in choosing information. College educators should combine the ideological and political education of college students with new media education, and use the big data platform to organically combine each step of analysis, investigation and solution. Colleges and universities should hold more seminars and trainings for ideological and political workers, which aims to enhance the capability of ideological and political educators to handle information and improve their information attainment.

\subsection{Enrich content of college students' ideological and political work}

In the era of big data, the teaching content should be closed to real life so as to make ideological and political education more effective. We can use current social hotspots to stimulate college students' learning interest, and guide college students to analyze the hot events from appearance to essence, thereby avoiding college students from being influenced by incorrect thoughts, and set up values in line with contemporary socialism. The education content can also combine with the current global situation and the interests of contemporary college students. It can not only broaden the horizons of college students, but also improve their ability to find and solve problems through actual situation analysis, so as to achieve the goal of ideological and political education. 


\subsection{Improve method of college students' ideological and political work}

First of all, we need to master information technology and methods of big data, and establish a set of early warning mechanism to deal with college students emergencies, by using the flexible means of big data to deal with massive data, so that the ideological and political education work can be more targeted. Second, colleges and universities should keep pace with the times and use more scientific ideological and political work research methods, not only quantitative research but also qualitative research. In addition, the big data platform for ideological and political education for university students across the country requires the active participation and development of major universities. This platform can not only facilitate the collection and analysis of data information, but also promote the exchange of college students' ideological and political education among colleges and universities, so as to provide us with a solid foundation for improving the effectiveness of ideological and political work for college students.

\subsection{Establish a favorable environment for ideological and political work}

The great influence of the environment on the college students is not reflected on the surface, but also changes the behavior habit and the state of thought imperceptibly. To improve the effectiveness of college students' ideological and political education, we must create a favorable ideological and political education environment for college students. Society, schools and families should take responsibility for creating a good learning and living environment for students. Universities should explore the similarities and differences in school education and family education in macro terms, so as to make up for deficiencies in the family's ideological education. Educators in colleges and universities should take the initiative to understand the students' specific circumstances, such as the growth environment, personality characteristics, so that we can teach students in accordance with their aptitude and create different teaching schemes for different students to achieve more targeted ideological and political education. Educators should actively maintain contact with students' parents and establish a sound campus-family communication system. Parents of students should know more about their children's living conditions and mental state through the school's educators, find problems and solve problems timely, resolve negative emotions for children, and enable them to grow up in a good environment.

\subsection{Improve the management mechanism of ideological and political work}

To improve the effectiveness of the ideological and political work of college students, we should establish and improve the management mechanism of ideological and political work for college students. First of all, the leadership mechanism for ideological and political work in universities should be under the unified leadership of the party committee, unanimous cooperation of the party and government, and teachers and students complement each other, and teachers in all departments should actively participate. A special working group should be set up to control the work of ideological and political education of college students and to review and revise the program in time, and to promote and supervise the newly established work mechanism at the same time. This special working group should hold regular meetings, control, supervise and summarize the work results of the previous stage, and carry out research and arrangements for the next stage of work. A new system of student management needs to be established and improve the management system of ideological and political work, thus improving the effectiveness of ideological and political work of college students.

\section{Conclusion}

There is no doubt that the ideological and political education of college students is of great significance. It can not only play a role in consolidating the economic foundation and the superstructure but also is an indispensable part of the ideological work of college students in universities. This paper discusses the connotation and problems of college students' ideological and political education in the era of big data, and proposes relative solutions on this basis. It aims to 
reduce the negative impact of big data technology and provide a favorable environment for college students' healthy and all-round development.

\section{References}

[1] Research on the method of education method of ideological and political science in university of big data. Shoulin Wang. Ideological and Political Education Research. 2015

[2] Big data era network thought politics education. Shuxiang, Hu, Yujing Xie. Studies in Ideological Education. 2013

[3] Policy Intensions and the Folds of the Self [J]. P. Taylor Webb, Kalervo N. Gulson. Educ Theory. 2013 (1)

[4] Research on the ideological and political education work of university students in the big data era. Peipei He, Yan Li. Education exploration. 2015

[5] Staging the Crisis: Teaching, Capital, and the Politics of the Subject [J]. Noah De Lissovoy. Curriculum Inquiry. 2010 (3) 